\title{
Pengaruh penggunaan pupuk daun "Organik" terhadap produktivitas dan kualitas rumput gajah (Pennisetum purpureum CV. Hawai) sebagai hijauan pakan
}

\author{
Badat Muwakhid *, Usman Ali \\ Fakultas Peternakan, Universitas Islam Malang, Malang, 65144 \\ *Correspondence: badatmalang@gmail.com
}

Received: April 9 ${ }^{\text {th }}, 2020$; Accepted: January 6 ${ }^{\text {th }}, 2021$; Published online: March 18 ${ }^{\text {th }}, 2021$

\begin{abstract}
Abstrak
Tujuan: Rumput gajah merupakan hijauan pakan ternak yang banyak dimanfaatkan oleh peternak sebagai pakan. Pertumbuhan rumput gajah dapat ditunjang dengan pemberian pupuk yang sesuai. Tujuan dari penelitian ini adalah menentukan dosis pupuk daun "organik" yang sesuai untuk mendapatkan produksi dan kualitas hijauan yang maksimal.

Metode: Metode penelitian yang digunakan adalah percobaan lapang. Rancangan acak lengkap (RAL) dengan lima ulangan digunakan dalam penelitian ini. Perlakuan pada penelitian ini adalah P0 (kontrol), P1 (5\% pupuk daun "organik"), P2 (10\% pupuk daun "organik") dan P3 (15\% pupuk daun "organik").

Hasil: Hasil penelitian ini menunjukkan bahwa pemberian dosis pupuk daun "organik" dengan persentase yang berbeda memberikan pengaruh yang sangat nyata $(\mathrm{P}<0,01)$ terhadap kandungan bahan kering (BK), bahan organik (BO), lemak kasar (LK), serat kasar (SK), bahan ekstrak tanpa nitrogen (BETN), jumlah produksi segar, produksi bahan kering (BK) dan produksi bahan organik $(\mathrm{BO})$ rumput gajah. Perbedaan yang nyata $(\mathrm{P}<0,05)$ pada kadar dan produksi PK rumput gajah juga diperlihatkan antar perlakuan.

Kesimpulan: Berdasarkan peningkatkan kuantitas produksi hijauan dan kualitas pakan yang dihasilkan pada penelitian ini, pemberian dosis 15\% pupuk daun "organik" menunjukkan hasil yang paling baik.
\end{abstract}

Kata Kunci: Kualitas hijauan; Produksi hijauan; Pupuk daun organik; Rumput gajah

Abstract

Objective: Elephant grass is a forage that is commonly used as feed. The growth of elephant grass can be supported by applying appropriate fertilizers. The purpose of this study was to determine the appropriate level of "organic" leaf fertilizer to obtain maximum production and quality.

Methods: Field experiment using a completely randomized design (CRD) with 5 replication was used in this study. The treatments were P0 (control), P1 (5\% "organic" leaf fertilizer), P2 (10\% "organic" leaf fertilizer), and P3 (15\% "organic" leaf fertilizer). 
Results: The results of this study indicate that the treatment of different doses of "organic" leaf fertilizer had significant effect $(\mathrm{P}<0.01)$ on forage quality (dry matter, organic matter, crude fat, crude fiber and nitrogen free extract content) and also fresh, dry matter, and organic matter production of elephant grass. The treatment also had a significant effect $(\mathrm{P}<0.05)$ on crude protein levels and production of elephant grass.

Conclusions: Based on this study, the dosage of 15\% "organic" foliar fertilizer showed the best results on increasing the quantity and quality of Pennisetum purpureum.

Keywords: Elephant grass; Forage production; Forage quality; Organic leaf fertilizers

\section{PENDAHULUAN}

Hijauan pakan ternak adalah sumber makanan utama untuk ternak ruminansia karena di dalamnya terkandung zat-zat makanan untuk memenuhi kebutuhan hidup pokok dan produksi. Pemilihan jenis hijauan pakan ternak dapat berdasarkan sifatnya seperti palatable, mudah dicerna, memiliki kandungan zat makanan yang mencukupi kebutuhan ternak, mudah didapatkan, mudah ditanam, memiliki siklus yang pendek dan dapat tumbuh kembali setelah panen. Rumput merupakan tumbuhan yang umum digunakan sebagai sumber pakan hijauan bagi ternak ruminansia di Indonesia. Rumput gajah menjadi jenis yang populer dikalangan peternak. Pada umumnya peternak rakyat menanam rumput gajah dengan menanamkan pols, karena cara ini mudah tumbuh dan cepat berproduksi, tetapi cara ini tidak praktis dalam penanamannya jika dibandingkan dengan sistem pembibitan melalui stek [1]. Keunggulan rumput gajah memiliki hasil produksi tinggi, menurut Purwawangsa dan Putera [1], rumput gajah yang di tanam pada tanah aluvial dengan pemupukan yang baik, dapat menghasilkan produksi 30 ton/ha/tahun. Menurut Skerman dan Riveros [2] rumput gajah memiliki kandungan bahan kering (BK) 20,0\%, bahan organik (BO) 86,05, lemak kasar (LK) 2,06\%, serat kasar (SK) 29,7\%, bahan ekstrak tanpa nitrogen (BETN) 43,9\%. Jenis pupuk pada dasarnya ada dua yaitu organik dan anorganik. Pupuk organik bisa diproduksi dari berbagai macam bahan contohnya serbuk gergaji, sisa tanaman, kotoran hewan, limbah rumah tangga, limbah pasar, limbah media jamur, limbah pabrik hingga pupuk hijau. Menurut Hartatik et al. [3], kualitas pupuk yang dihasilkan akan beragam sesuai perbedaan bahan yang digunakan dan proses pembuatannya.

Pupuk daun "organik" merupakan gabungan dari urin ternak terfermentasi dengan zat pengatur tumbuh yang di sediakan dari bahan-bahan organik. Dalam upaya untuk mencapai produksi yang berasaskan zero waste, maka dapat digunakan urin ternak sebagai penunjang pertumbuhan rumput gajah. Urin ternak yang difermentasi dapat diaplikasikan pada tanaman karena mengandung jenis hormon auksin yang dapat mempengaruhi perkembangan sel serta proses terbentuknya kalus. Urin ternak terfermentasi mengandung $1,20 \% \mathrm{~N}$; 0,5\% P; $1,50 \% \mathrm{~K} ; 25,5 \mathrm{mg} / \mathrm{l} \mathrm{Ca}$; dan 0,706\% Corganik [4]. Teknologi fermentasi yang dimanfaatkan dapat memberikan keuntungan seperti peningkatan nilai gizi suatu bahan karena adanya mikroorganisme yang memecah komponen kompleks menjadi lebih sederhana [5]. Menurut Ramadan et al. [6], zat pengatur tumbuh berperan merangsang tumbuhnya tanaman dalam upaya membantu pembentukan fitohormon yang ada di dalam tanaman serta menggantikan fungsi dan peran hormon. Pengaplikasian pupuk organik yang berasal dari urin ternak menurut hasil penelitian Djufry dan Ramlan [7] lebih efektif dilakukan dengan metode semprot daripada metode siram. Hasil penelitian Pary [8] menunjukkan bahwa pemanfaatan pupuk organik hasil pemerasan daun lamtoro sampai dengan 60 gr mendapatkan pertumbuhan tanaman sawi terbaik. Sedangkan Amin et al. [9] menyatakan bahwa pemberian pupuk organik cair dari proses fermentasi limbah rumen sapi, mampu meningkatkan produksi rumput gajah. Berdasarkan latar belakang tersebut, maka dilakukan penelitian ini 
dengan menggunakan pupuk daun "organik" pada rumput gajah untuk mengetahui pengaruhnya terhadap kualitas dan kuantitas produksi rumput gajah yang dihasilkan.

\section{MATERI DAN METODE}

\section{Materi}

Materi yang digunakan pada penelitian ini meliputi pupuk daun "organik" dan bibit rumput gajah CV Hawai dalam keadaan pols, dengan rata-rata panjang perpols adalah $10 \mathrm{~cm}$.

\section{Pembuatan Pupuk}

Pupuk daun "organik" merupakan campuran dari urin terfermentasi 95\% dan zat pengatur tumbuh 5\%. Prosedur pelaksanaan fermentasi urin dan pembuatan zat pengatur tumbuh sebagai berikut.

\section{Pelaksanaan Fermentasi Urin}

Tahapan fermentasi urin dilakukan dengan urutan kegiatan penampungan urin sapi perah Friesian Holstein (FH), penyaringan isi rumen, penyiapan molasses, air cucian beras, empon-empon yang terdiri dari kunyit (Curcuma longa), temu ireng (Curcuma seroginosa), dan temu lawak (Curcuma zanthorrhiza). Dilanjutkan dengan menyiapkan daun pahitan (Tithonia diversifolia) dan daun lamtoro (Leucaena leucocephala). Bahan bahan berbentuk padatan yang telah disiapkan ditumbuk lalu diperas, sehingga semua bahan berupa cairan. Selanjutnya dilakukan pencampuran semua bahan yang telah berbentuk cairan dengan proporsi urin $60 \%$, isi rumen $15 \%$, molasses $10 \%$, air cucian beras $3 \%$, empon-empon $6 \%$, daun pahitan 3\%, daun lamtoro 3\%, dicampur lalu diaduk hingga merata, dan ditutup hingga tujuh hari.

\section{Pembuatan Zat Pengatur Tumbuh}

Pembuatan zat pengatur tumbuh dilakukan dengan menyiapkan kelompok bahan A yang terdiri dari bonggol pisang, rebung bambu, pucuk daun rumput gajah dan kecambah, masing masing ditumbuk sampai halus, kemudian diperas dan disaring. Bahan B yang berupa gula merah yang ditambahkan air sebanyak sepertiga dari bobot gula merah, selanjutnya direbus hingga mencair, kemudian didinginkan dan disaring. Bahan $C$ yang terdiri dari air kelapa yang disaring dan bahan $\mathrm{D}$ berupa cairan isi rumen yang disaring. Selanjutnya dilakukan pencampuran bahan A (20\%), bahan B $(20 \%)$, bahan C $(20 \%)$, dan bahan D $(40 \%)$. Hasil pencampuran diaduk hingga merata, kemudian ditutup hingga empat hari.

\section{Metode}

Metode penelitian ini adalah percobaan lapang dengan menggunakan rancangan Rancangan Acak Lengkap (RAL) dengan empat perlakuan dan lima ulangan, model matematis sebagai berikut:

$$
Y i j=\mu+\tau i+\varepsilon i j
$$

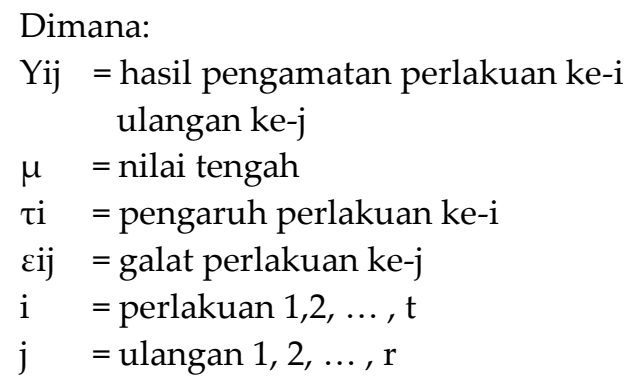

Adapun perlakuan yang diberikan yaitu: $\mathrm{P} 0=$ perlakuan kontrol tanpa penyemprotan pupuk daun "organik"

$\mathrm{P} 1$ = penyemptotan pupuk daun "organik" dosis $5 \%$ setara dengan $5 \mathrm{ml}$ P2 = penyemptotan pupuk daun "organik" dosis $10 \%$ setara dengan $10 \mathrm{ml}$ P3 = penyemptotan pupuk daun "organik" dosis $15 \%$ setara dengan $15 \mathrm{ml}$

\section{Tempat dan Waktu Penelitian}

Penelitian dilakukan pada lahan persawahan beririgasi, di desa Tegalweru Kecamatan Dau, Kabupaten Malang. Jenis tanah pada lahan adalah tanah aluvial, dengan $\mathrm{pH}=6,50, \mathrm{~N}=0,09 \%, \mathrm{P}_{2} \mathrm{O}_{5}=12,99$ $\mathrm{mgkg}^{-1}, \mathrm{~K}_{2} \mathrm{O}=34,43 \mathrm{mg} / 100 \mathrm{~g}$ dan $\mathrm{KTK}=20,43$ el $\mathrm{mol} / \mathrm{kg}$. Penelitian dimulai dari tanggal 14 Juli 2019 sampai dengan 10 Oktober 2019.

\section{Variabel dan Prosedur Penelitian}

Variabel yang diamati pada penelitian ini meliputi Jumlah produksi segar, produksi bahan kering, produksi bahan organik dan 
produksi protein kasar rumput gajah, kandungan/persentase bahan kering (BK), bahan organik $(\mathrm{BO})$, protein kasar (PK), serat kasar (SK), lemak kasar (LK), dan bahan ekstrak tanpa nitrogen (BETN) [10]. Adapun proses penelitian dilakukan melalui prosedur sebagai berikut :

1. Persiapan lahan: tanah yang akan ditanami rumput gajah ini dibajak terlebih dahulu sebanyak 2 kali lalu diratakam dan di buat 20 bedengan, masing masing lebar 1 meter persegi, tinggi bedengan $30 \mathrm{~cm}$, jarak antar bedengan $70 \mathrm{~cm}$,

2. Pemilihan rumput gajah: bibit dipilih dari rumput gajah cultivar Hawai.

3. Penanaman bibit rumput gajah: penanaman menggunakan sistem pols, pols berasal dari rumput gajah yang baru dipanen, dalam kondisi tanpa daun, dimasukkan ke dalam tanah yang telah dilubangi sedalam 7-10 cm, lalu ditutup dengan tanah, jarak tanam antar antar baris $70 \mathrm{~cm}$ dan jarak dalam baris $50 \mathrm{~cm}$, setiap lubang diberi tiga batang rumput gajah, sehingga pada penelitian ini membutuhkan 360 satuan pols.

4. Pengairan: pengairan dilakukan setiap tiga hari sekali dengan cara dialiri air sampai menggenang, lalu air dibuang hingga tuntas.

5. Pembersihan gulma: pembersihan gulma dilakukan seminggu sekali.

Persiapan perlakuan : rumput ditanam hingga umur 40 hari untuk menjamin bahwa semua unit tanaman percobaan telah hidup dengan sempurna, kemudian dipotong secara serentak dengan pemotongan dilakukan pada $3 \mathrm{~cm}$ di atas tanah, selanjutnya semua pangkal sisa pemotongan dibiarkan sampai masing masing unit tanaman percobaan telah tumbuh daun kembali, sampai umur 10 hari dari pemotongan serentak, selanjutnya dilakukan penyemprotan pupuk daun "organik", dan dibiarkan daun tumbuh merespon pupuk yang disemprotkan, dan agar diperoleh interval perlakuan yang sama, penyemprotan dilakukan pada hari ke-10, 20, dan 30. Setelah penyemprotan hari ke-30, juga dibiarkan daun tumbuh merespon pupuk yang telah disemprotkan bersamaan dalam waktu 10 hari, selanjutnya dipotong untuk diamati produktivitas dan kualitasnya.

Pupuk daun "organik" tersusun atas urin terfermentasi $95 \%$ dan zat pengatur tumbuh 5\%. Cara pemupukan disemprotkan $100 \mathrm{ml}$ pada setiap rumpun rumput gajah, level dosis pemupukan di tetapkan dalam persentase pupuk "organik" dalam air.

6. Pemanenan: rumput gajah dipanen pada usia 40 hari dengan pemotongan dilakukan pada $3 \mathrm{~cm}$ di atas tanah, dan ditimbang pada masing masing unit percobaan, untuk mengukur jumlah produksi segar.

7. Dari masing masing unit percobaan yang telah ditimbang, diambil 3 pohon lengkap batang dan daun, diambil secara acak, selanjutnya dipotong berukuran kurang lebih $3 \mathrm{~cm}$. Sampel kemudian ditimbang sebagai bobot awal pengeringan (kering udara), dimasukkan ke kantong plastik, ditutup dengan rapat dan dibawa ke laboratorium untuk dilakukan pengovenan. Pengovenan dilakukan pada suhu $65^{\circ} \mathrm{C}$ selama 48 jam kemudian ditimbang untuk mengetahui bobot akhir dalam pengukuran bahan kering udara. Masing-masing bahan digiling sehingga menghasilkan mesh ukuran 0,5 mm untuk disiapkan analisa kimiawi sesuai kebutuhan.

\section{Analisa Data}

Data yang diperoleh dari penelitian lalu dianalisa menggunakan Analisa Ragam (Anova) jika ada data yang menunjukkan pengaruh nyata dilanjutkan dengan uji Beda Nyata Terkecil (BNT).

\section{HASIL}

Produksi hijauan rumput gajah dapat dilihat pada Tabel 1. Hasil dari analisa statistik menunjukkan bahwa produksi segar hijauan, produksi $\mathrm{BK}$, dan produksi $\mathrm{BO}$ rumput gajah menunjukkan perbedaan yang sangat nyata $(\mathrm{P}<0,01)$ antar perlakuan, tetapi pada variabel produksi PK diperoleh hasil analisa statistik perbeda nyata $(\mathrm{P}<0,05)$ antar perlakuan. Produksi segar, produksi bahan 
Tabel 1. Produksi tanaman rumput gajah dengan pemberian dosis pupuk yang berbeda

\begin{tabular}{lcccc}
\hline \multicolumn{1}{c}{ Variabel } & P0 & P1 & P2 & P3 \\
\hline Produksi segar $\left(\mathrm{kg} / \mathrm{m}^{2}\right)$ & $3,09^{\mathrm{A}}$ & $4,07^{\mathrm{B}}$ & $4,31^{\mathrm{C}}$ & $4,74^{\mathrm{D}}$ \\
Produksi BK $\left(\mathrm{kg} / \mathrm{m}^{2}\right)$ & $0,5^{\mathrm{A}}$ & $0,73^{\mathrm{B}}$ & $0,77^{\mathrm{BC}}$ & $0,86^{\mathrm{C}}$ \\
Produksi BO $\left(\mathrm{kg} / \mathrm{m}^{2}\right)$ & $0,46^{\mathrm{A}}$ & $0,55^{\mathrm{B}}$ & $0,59^{\mathrm{B}}$ & $0,68^{\mathrm{C}}$ \\
Produksi PK $\left(\mathrm{kg} / \mathrm{m}^{2}\right)$ & $0,07^{\mathrm{a}}$ & $0,10^{\mathrm{b}}$ & $0,11^{\mathrm{c}}$ & $0,13_{\mathrm{c}}$ \\
\hline
\end{tabular}

Keterangan : Superskrip (a-c) yang berbeda pada baris yang sama menunjukkan adanya perbedaan yang nyata $(\mathrm{P}<0,05)$. Superskrip $(\mathrm{A}-\mathrm{D})$ yang berbeda pada baris yang sama menunjukkan adanya perbedaan yang sangat nyata $(\mathrm{P}<0,01)$. Perlakuan $\mathrm{P} 0=$ Perlakuan kontrol, tanpa penyemprotan pupuk daun “organik", P1 = penyemprotan pupuk organik 5\% dalam air, P2 = penyemprotan pupuk organik $10 \%$ dalam air, $\mathrm{P} 3=$ penyemprotan pupuk organik $15 \%$ dalam air. $\mathrm{BK}=\mathrm{Bahan}$ kering, $\mathrm{BO}=\mathrm{Bahan}$ Organik, PK = Protein Kasar.

kering, produksi bahan organik, dan produksi protein kasar hijauan selalu meningkat disetiap peningkatan doses pupuk, dengan produksi tertinggi dihasilkan oleh perlakuan P3 (dosis pupuk daun "organik" 15\%).

Hasil penelitian mengenai kualitas hijauan rumput gajah yang disemprot dengan berbagai dosis pupuk daun "organik" tersaji pada Tabel 2. Berdasarkan hasil analisa statistik, data menunjukkan bahwa terdapat pengaruh yang sangat nyata $(\mathrm{P}<0,01)$ dari perlakuan dosis penyemprotan pupuk dengan kandungan $\mathrm{BK}, \mathrm{BO}, \mathrm{SK}, \mathrm{LK}$, dan BETN rumput gajah. Kandungan PK pada rumput gajah dilaporkan memiliki perbedaan yang nyata $(\mathrm{P}<0,05)$ antar perlakuan yang diberikan. Kandungan BK, BO, PK, SK, LK, dan BETN rumput gajah selalu meningkat dengan kandungan tertinggi pada $\mathrm{BK}=$ $18,13 \%$, BO $=79,58 \%$, PK $=14,68 \%$, SK $=$ $23,58 \%$, LK $=3,36 \%$, dan $\mathrm{BETN}=51,16 \%$ dihasilkan oleh perlakuan P3 (dosis pupuk daun "organik" 15\%).

\section{PEMBAHASAN}

\section{Produksi Hijauan}

Produksi segar rumput gajah yang diberikan pupuk daun "organik" 5\%, 10\% dan $15 \%$, masing masing $4,07\left(\mathrm{~kg} / \mathrm{m}^{2}\right)$ setara dengan 244,200 (ton/Ha/thn) 4,31 (kg/m²) setara dengan 258.600 (ton/Ha/thn), dan 4,74 $\left(\mathrm{kg} / \mathrm{m}^{2}\right)$ setara dengan 284.400 (ton/Ha/thn). Produksi rumput gajah hasil penelitian ini lebih tinggi dibanding rata produksi rumput gajah pada umumnya. Menurut Rukmana [11] produksi rumput gajah berkisar antara 100200 ton/Ha/thn., angka ini sepadan dengan produksi rumput gajah pada perlakuan kontrol yaitu 3,09 $\left(\mathrm{kg} / \mathrm{m}^{2}\right)$ setara dengan 185.400 (ton/Ha/thn). Peningkatan produksi pada penelitian ini disebabkan oleh pasokan unsur hara yang terkandung pada pupuk daun "organik" dan aktivitas zat pengatur tumbuh. Menurut George dan Sherrington [12], penggunaan zat pengatur tumbuh (ZPT) dalam media tanaman mampu merangsang

Tabel 2. Kualitas hijauan pada rumput gajah dengan perlakuan pemberian dosis pupuk yang berbeda

\begin{tabular}{lrrrr}
\hline \multicolumn{1}{c}{ Kandungan } & P0 & P1 & \multicolumn{1}{c}{ P2 } & P3 \\
\hline BK (\%) & $17,15^{\mathrm{A}}$ & $17,81^{\mathrm{B}}$ & $17,99^{\mathrm{B}}$ & $18,13^{\mathrm{C}}$ \\
BO (\%) & $69,27^{\mathrm{A}}$ & $75,64^{\mathrm{B}}$ & $76,34^{\mathrm{B}}$ & $79,58^{\mathrm{C}}$ \\
PK (\%) & $13,27^{\mathrm{a}}$ & $14,46^{\mathrm{b}}$ & $14,66^{\mathrm{C}}$ & $14,68^{\mathrm{C}}$ \\
SK (\%) & $28,50^{\mathrm{C}}$ & $26,29^{\mathrm{B}}$ & $24,55^{\mathrm{B}}$ & $23,58^{\mathrm{A}}$ \\
LK (\%) & $2,22^{\mathrm{A}}$ & $2,92^{\mathrm{B}}$ & $3,28^{\mathrm{C}}$ & $3,36^{\mathrm{C}}$ \\
BETN (\%) & $42,35^{\mathrm{A}}$ & $47,92^{\mathrm{B}}$ & $49,37^{\mathrm{C}}$ & $51,16^{\mathrm{C}}$ \\
\hline
\end{tabular}

Keterangan : Superskrip (a-c) yang berbeda pada baris yang sama menunjukkan adanya perbedaan yang nyata $(\mathrm{P}<0,05)$. Superskrip (A-D) yang berbeda pada baris yang sama menunjukkan adanya perbedaan yang sangat nyata $(\mathrm{P}<0,01)$. Perlakuan $\mathrm{P} 0=$ Perlakuan kontrol, tanpa penyemprotan pupuk daun "organik", P1 = penyemprotan pupuk organik $5 \%$ dalam air, $\mathrm{P} 2$ = penyemprotan pupuk organik $10 \%$ dalam air, $\mathrm{P} 3=$ penyemprotan pupuk organik $15 \%$ dalam air. BK = Bahan kering, $\mathrm{BO}=$ Bahan Organik, $\mathrm{PK}=$ Protein Kasar, SK = Serat Kasar, BETN = Bahan Ekstrak Tanpa Nitrogen . 
pertumbuhan namun dapat bersifat sebagai inhibitor apabila digunakan melebihi konsentrasi optimum.

Produksi segar rumput gajah tertinggi dihasilkan oleh perlakuan P3 yang memiliki dosis pupuk daun "organik" 15\%, sedangkan produksi segar terendah dihasilkan oleh perlakuan kontrol. Menurut Muhakka et al. [13] peningkatan produksi hijauan dikarenakan pupuk daun "organik" menyediakan $\mathrm{N}$ yang dibutuhkan oleh tumbuhan untuk pertumbuhan vegetatif contohnya pada daun, akar dan batang. Peningkatan produksi segar rumput gajah juga dipengaruhi oleh adanya peningkatan tinggi tanaman. Berdasarkan studi yang dilakukan oleh Nuriyasa et al. [14], tinggi rumput gajah yang diberi pemupukan pupuk organik dengan dosis 75.000 liter/ha dapat meningkatkan rataan tinggi dari $71,67 \mathrm{~cm}$ menjadi $78,50 \mathrm{~cm}$.

Penelitian yang dilakukan oleh Prayogo et al. [15] melaporkan bahwa peningkatan dosis pemberian pupuk organik akan meningkatkan tinggi rumput gajah juga diiringi peningkatan produksi segarnya. Hal tersebut juga dipengaruhi oleh tersedianya unsur hara yang lebih banyak dari pupuk organik yang diberikan. Hasil penelitian ini juga didukung oleh Mappanganro et al. [16] yang mana terjadi peningkatan tinggi tanaman rumput gajah mini yang signifikan seiring dengan peningkatan dosis pupuk cair berbasis urin ternak yang diberikan pada tanaman. Menurut penelitian tersebut unsur hara mikro (N, P, K, S, Ca, Mg) dan mikro (B, $\mathrm{Mo}, \mathrm{Cu}, \mathrm{Fe}, \mathrm{Mn}$ ) mempunyai peranan penting terhadap pertumbuhan rumput gajah.
Peningkatan jumlah daun pada rumput juga akan memberikan dampak positif terhadap produksi segar hijauan seperti dijelaskan oleh Kastalani et al. [17] bahwa unsur $\mathrm{N}$ yang diperoleh dari pupuk organik merupakan salah satu komponen pembentuk klorofil sehingga unsur ini penting untuk pertumbuhan daun.

Produksi bahan kering rumput gajah juga mengalami peningkatan produksi sejalan dengan bertambahnya dosis pupuk daun "organik" yang diberikan. Hasil ini sesuai dengan hasil penelitian Keraf et al. [18] yang melaporkan bahwa level pemberian pupuk yang lebih tinggi akan meningkatkan produksi bahan kering karena asupan unsur haranya meningkat. Menurut Nuriyasa et al. [14] semakin banyak pemberian pupuk berupa biourin pada tanaman akan meningkatkan pertumbuhan dan produksi hijauan. Hal tersebut disebabkan oleh ketersediaan unsur hara yang semakin banyak bagi tanaman untuk pertumbuhan dan produksi. Menurut Laksmita et al. [19] timbunan hasil fotosintesis tanaman diseluruh bagian tubuhnya akan mempengaruhi berat kering tanaman tersebut. Semakin baik proses fotosintesis maka semakin baik juga penyimpanan cadangan makanan yang ditranslokasikan menjadi berat kering tanaman.

Hasil produksi bahan organik pada rumput gajah tertinggi mencapai $0,68 \mathrm{~kg} / \mathrm{m}^{2}$ pada perlakuan P3 (dosis pupuk daun "organik" 15\%). Hasil dari penelitian ini juga sejalan dengan Keraf et al. [18] yaitu dengan meningkatnya level pemupukan maka meningkatkan produksi BO. Peningkatan

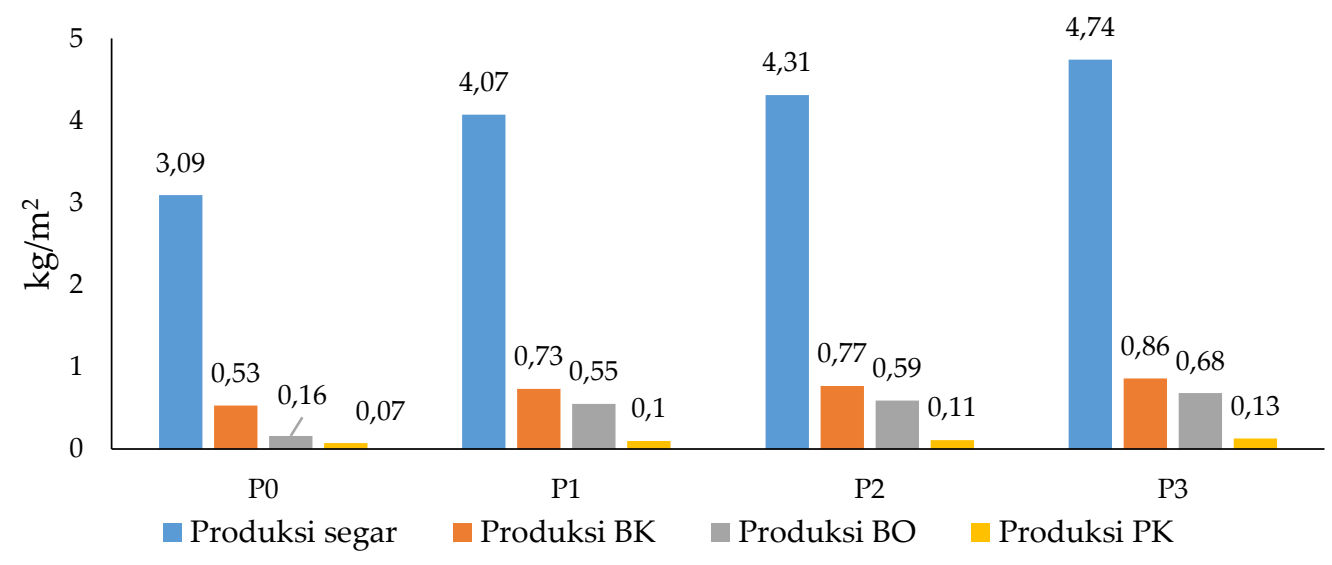

Gambar 1. Produksi tanaman rumput gajah dengan pemberian dosis pupuk yang berbeda 
produksi BO juga menyebabkan produksi PK meningkat seiring dengan peningkatan dosis pemberian pupuk daun "organik". Produksi PK tertinggi dihasilkan oleh P3 yaitu 0,13 $\mathrm{kg} / \mathrm{m}^{2}$. Menurut Keraf et al. [18] hal ini karena dengan adanya peningkatan penyerapan unsur $\mathrm{N}$ pada tanaman dapat meingkatkan biomassa tanaman yang juga dapat menyebabkan adanya peningkatan pada produksi PK.

\section{Kualitas Hijauan}

Perlakuan yang diberikan menunjukkan pengaruh yang sangat nyata $(\mathrm{P}<0,01)$ terhadap persentase kandungan BK rumput gajah. Terdapat pola peningkatan kandungan BK seiring dengan peningkatan dosis pupuk yang disemprotkan. Nitrogen pada pupuk daun berfungsi menyusun protein, asam nukleat, nuklotida dan klorofil pada tanaman [20]. Tanaman yang diberikan pupuk nitrogen secara efektif dapat mengkibatkan kandungan protein, asam nukleat, dan nuklotida dalam jumlah tinggi, sedangkan kandungan air dalam tanaman relatif tetap. Dengan demikian rumput yang diberikan pupuk secara efektif akan meningkatkan kandungan bahan kering pada batang dan daunnya. Hasil dari penelitian ini sejalan dengan hasil penelitian yang dilakukan oleh Sumarsono et al. [21] bahwa peningkatan dosis pemberian pupuk menyebabkan peningkatan kandungan BK (bahan kering) pada rumput. Stomata merupakan organ penting dalam proses fotosintesis dan juga transpirasi pada tanaman. Stomata berfungsi sebagai tempat pertukaran $\mathrm{CO}_{2}$ di daun untuk proses fotosintesis, dan sebagai tempat penguapan air dalam proses transpirasi. Hasil penelitian yang dilakukan oleh Arista dkk, [22] pada tanaman tebu menunjukkan bahwa pemberian silika dapat meningkatkan kerapatan stomata yang menyebabkan jumlah stomata semakin banyak, sehingga dapat meningkatkan laju transpirasi dan penyerapan $\mathrm{CO}_{2}$ untuk fotosintesis.

Kandungan bahan organik pada rumput gajah pada penelitian ini juga dilaporkan mengalami peningkatan seiring dengan peningkatan dosis pemberian pupuk daun "organik". Hal tersebut dapat dikarenakan unsur hara yang terkandung pada pupuk daun "organik" mampu diserap secara optimal oleh rumput gajah, karena penyemprotan dilakukan pada sore hari. Menurut Nasruddin dan Rosmawati [23], faktor yang mempengaruhi efektifitas pemupukan melalui hanya sementara, sehingga jika cairan yang menempel di permukaan daun habis, maka suplai haranya berhenti. Kecepatan hilangnya cairan tersebut dipengaruhi oleh faktor intensitas cahaya dan suhu. Semakin tinggi intensitas cahaya pada suatu tanaman, maka hilangnya cairan pupuk daun akan semakin cepat, begitu pula suhu lingkungan yang tinggi semakin cepat hilangnya cairan pupuk.

Kadar BO rumput gajah yang mengalami peningkatan akibat adanya peningkatan pada dosis penyemprotan pupuk daun "organik" ini juga dipengaruhi oleh adanya bahan tambahan yang digunakan saat fermentasi pembuatan pupuk seperti empon-empon, air cucian beras. Empon-empon pada dasarnya menyediakan karbohidrat dan air cucian beras menyediakan vitamin B1 untuk memacu pertumbuan bakteri pendegradasi urin, agar urin terfermentasi sebagai pupuk dapat diserap oleh daun dengan sempurna. Selain itu, air cucian beras yang memiliki kandungan vitamin B1 juga bermanfaat untuk memacu pertumbuhan tanaman. Wulandari dkk [24] menjelaskan bahwa air cucian beras yang mengandung protein dan vitamin B1 memiliki mekanisme metabolisme yang dapat merombak karbohidrat menjadi energi, sehingga mampu memacu pertumbuhan tanaman, sedangkan kandungan air dalam tanaman relatif tetap. Dengan demikian, rumput yang diberikan pupuk dengan tambahan empon empon dan air cucian beras akan mampu meningkatkan kandungan bahan organik pada batang dan daunnya. Hal ini sesuai dengan hasil penelitian Sufriyanto et al. [25] yang menunjukkan hasil bahwa semakin banyak bahan tambahan yang digunakan untuk fermentasi pupuk cair organik maka akan memberikan pengaruh terhadap peningkatan kadar BO rumput.

Kandungan PK terendah ditunjukkan oleh perlakuan kontrol, sementara yang tertinggi dimiliki oleh perlakuan P3 (dosis pupuk daun "organik" 15\%). Menurut 
Mandie et al. [26] pemberian pupuk melalui daun memberikan respon yang cepat. Pemenuhan unsur hara melalui pemupukan daun dapat meningkatkan laju fotosintesis. Peningkatan laju fotosintesis dapat memicu pertumbuhan tanaman. Tanaman yanga diberikan pupuk melalui daun, akan segera mengabsorpsi unsur hara yang diberikan, termasuk nitrogen. Nitrogen pada pupuk berfungsi menyusun protein [20], sehingga tanaman yang dipupuk nitrogen melalui cara pemupukan daun akan membentuk protein lebih banyak dan cepat.

Hasil penelitian ini sejalan dengan Hasan et al. [27] yang mana pemberian pupuk cair dengan dosis yang semakin tinggi mampu menghasilkan rumput dengan kandungan protein kasar yang semakin tinggi juga. Menurut penelitian tersebut, hal ini dipengaruhi oleh semakin meningkatnya penyerapan $\mathrm{N}$ pada tanaman karena penggunaan pupuk cair. Faktor lain yang juga mempengaruhi kandungan PK pada rumput gajah menurut Lestari et al [28] adalah interval waktu pemotongan atau defoliasi. Berdasarkan penelitian tersebut, pemberian pupuk organik cair pada rumput dengan interval defoliasi yang semakin lama akan semakin menurunkan kandungan PK rumput.

Perlakuan dosis pupuk daun pada penelitian ini, mendapatkan hasil semakin meningkatnya dosis pupuk daun "organik" otomatis semakin mningkat kandungan $\mathrm{N}$ yang di peroleh tanaman, hingga dosis pupuk daun "organik" 15\%, masih terjadi peningkatan produktifitas dan kualitas rumput yang di hasilkan. Hal ini menunjukkan bahwa pemberian pupuk daun hingga dosis $15 \%$ masih belum terpenuhi kebutuhan Nitrogen yang di butuhkan. Menurut Setyamidjaja [29], pemupukan yang optimal dapat dicapai apabila pupuk diberikan sesuai dengan kebutuhan tanaman. Bila pupuk melebihi volume optimum, maka dapat mengakibatkan keracunan pada tanaman. Tanaman dapat tumbuh dengan baik apabila unsur hara yang diberikan dalam jumlah seimbang dan sesuai dengan kebutuhan tanaman. Apabila sampai dengan dosis pupuk daun "organik $15 \%$ produktifitas dan kualitas rumput masih dimungkinkan optimalisasi pemenuhan $\mathrm{N}$ pada rumput percobaan belum terpenuhi.

Faktor lain yang juga mempengaruhi kandungan PK pada rumput gajah adalah interval waktu pemotongan atau defoliasi. Menurut Lestari et al. [28] pemberian pupuk organik cair pada rumput harus diimbangi dengan semakin pendeknya interval defoliasi, karena interval pemotongan yang menjamin optimalisasi produksi rumput diperoleh kandungan PK rumput yang tinggi. Optimalisasi kandungan PK pada rumput diperlukan untuk meningkatkan efisiensi produksi ternak ruminansia, karena tingkat kecernaan ruminansia dipengaruhi oleh ketersediaan PK yang memadai. Tillman et al. [30] menyebutkan bahwa faktor-faktor yang memengaruhi nilai kecernaan bahan kering ransum adalah komposisi kimia dalam ransum, proporsi bahan pakan ransum, tingkat protein ransum, serta persentase lemak dan mineral.

Kandungan serat kasar rumput gajah diukur dari batang dan daun hasil pemotongan rumput gajah selama penelitian. Kandungan serat kasar terbesar dimiliki oleh perlakuan kontrol sedangkan yang terendah ada pada perlakuan P3 (dosis pupuk daun “organik" 15\%). Menurut Setyamidjaja [29], Terbentuknya serat kasar pada tanaman dipengaruhi oleh banyaknya cekaman yang dialami oleh tanaman selama hidupnya. Semakin banyak tanaman mengalami cekaman atau semakin lama tanaman menjalani hidup yang secara simultan mendapatkan cekaman, maka akan semakin tinggi serat kasar yang terkandung.

Kombinasi penggunaan biourin dan zat pengatur tumbuh organik dapat langsung dimanfaatkan oleh tumbuhan untuk melakukan fotosintesis, dengan makin cepatnya proses fotosintesis berlangsung maka akan meningkatkan proses pembentukan klorofil, sehingga tanaman tidak banyak mendapatkan cekaman selama hidupnya, karena menurut Setyamidjaja [29], terbentuknya serat kasar pada tanaman dipengaruhi oleh banyaknya cekaman yang dialami oleh tanaman selama hidupnya. Semakin banyak tanaman mengalami cekaman atau semakin lama tanaman menjalani hidup yang secara simultan 
mendapatkan cekaman, maka akan semakin tinggi serat kasar yang terkandung.

Hasil penelitian ini kontradiksi dengan harapan umum pemenuhan kebutuhan pakan pada ternak ruminansia, karena Ternak ruminansia memiliki keistimewaan pada alat pencernaanya, yaitu memiliki rumen yang digunakan sebagai tempat fermentasi dan membantu pemecahan pakan berserat kasar tinggi, untuk menghasilkan volatile fatty acids (VFA) sebagai sumber energi. Produksi VFA banyak dipengaruhi oleh kualitas pakan yang dikonsumsi ternak, khususnya dalam hal kandungan serat kasar pakan [31].

Kandungan BETN rumput gajah terendah ada pada perlakuan kontrol sedangkan yang tertinggi ada pada perlakuan dosis pupuk daun "organik" 15\%. Kandungan BETN pada tanaman dipengaruhi oleh proprsi isi sel tanaman yang merupakan jenis karbohidrat non-struktural. Semakin besar proporsi karbohidrat nan-struktural pada isi sel tanaman menunjukaan proprsi karbohidrat struktural yang berupa sellulosa, hemisellulosa dalam proporsi semakin rendah. Tanaman yang diberikan pupuk melalui daun, dengan cepat mengabsorpsi unsur hara yang diberikan, sehingga dalam waktu singkat tanaman mampu membentuk komponen isi sel lebih dominan sebelum pembentukan komponen karbohidrat struktural terjadi, karbohidrat struktural merupakan metabolit secunder yang terbentuk sebagai respon adanya cekaman fisiologis selama waktu hidupnya. Menurut Fitriana et al. [32] kadar karbohidrat struktural tanaman akan mengalami peningkatan seiring dengan pertambahan umur, saat umur muda tanaman cenderung memiliki kadar karbohidrat struktural yang rendah.

Kandungan BETN juga dipengaruhi juga oleh proporsi isi sel tanaman yang merupakan jenis karbohidrat nonstruktural, dengan adanya penambahan zat pengatur tumbuh akan memperbaiki perkembangan sel tumbuhan, hal ini yang berpengaruh terhadap perbedaan kandungan BETN tiap perlakuan. Menurut Fitriana et al. [32] kadar BETN suatu tanaman juga akan mengalami perubahan seiring dengan pertambahan usia, saat usia muda tanaman cenderung memiliki kadar BETN yang rendah. Semakin besar proporsi karbohidrat nan-struktural pada isi sel tanaman menunjukaan proprsi karbohidrat struktural yang serat kasar dalam proporsi semakin rendah. Tanaman yang diberikan pupuk melalui daun, dengan cepat mengabsorpsi unsur hara yang diberikan, sehingga dalam waktu singkat tanaman mampu membentuk komponen isi sel lebih dominan sebelum pembentukan komponen karbohidrat struktural terjadi. Karbohidrat struktural terdiri dari sellulosa, hemisellosa, lignosellulosa yang juga berfungsi memperkuat tegakan tanaman, sehingga tanaman yang lebih cepat terbentuk karbohidrat nonstruktural akan terjadi kondisi batang tanaman lebih sukulen dan kurang keras, biasanya tanaman lebih mudah roboh. Karbohidrat struktural merupakan metabolit sekunder yang terbentuk sebagai respon adanya cekaman fisiologis selama waktu hidupnya. Menurut Fitriana et al [32] kadar karbohidrat struktural tanaman akan mengalami peningkatan seiring dengan pertambahan umur, saat umur muda tanaman cenderung memiliki kadar karbohidrat struktural (sellulosa, hemisellulosa) yang rendah.

\section{KESIMPULAN}

Penggunaan pupuk daun "organik" berupa campuran biourin dan zat pengatur tumbuh pada rumput gajah mampu meningkatkan produktivitas dan kualitas rumput gajah sebagai hijauan pakan. Hasil penelitian ini dapat meningkatkan efisiensi biaya produksi ternak ruminansia, karena sebagian biaya produksi rumput bisa dipenuhi dengan pemanfaatan limbah urin dari usaha peternakan itu sendiri. Dosis penyemprotan pupuk daun "organik" terbaik yang dapat diberikan adalah $15 \%$.

\section{KONFLIK KEPENTINGAN}

Penulis menyatakan tidak terdapat konflik kepentingan dengan pihak manapun terkait materi yang ditulis dalam naskah ini. 


\section{REFERENSI}

1. Purwawangsa, H. dan B. W. Putera. 2014. Pemanfaatan lahan tidur untuk penggemukan sapi. Risalah Kebijakan Pertanian dan Lingkungan. 1 (2): 92-96. Doi: 10.29244/jkebijakan.v1i2.10299.

2. Skerman, P.J., F. Riveros. 1990. Tropical grasses. FAO plant production series (23). Food and Agriculture of the United Nation, Roma.

3. Hartatik, W., Husnain dan L. R. Widowati. 2015. Peranan pupuk organik dalam peningkatan produktivitas tanah dan tanaman. J. Sumberdaya Lahan. 9 (2): 107120. Doi: 10.2018/jsdl.v9i2.6600.

4. Naswir. 2003. Pemanfaatan urin sapi yang difermentasi sebagai nutrisi tanaman. Pengantar Falsafah Sains. Program Pascasarjana. IPB. Bogor.

5. Marassing, J. S., W. B. Kaunang, F. Dompas, dan N. Bawole. 2013. Produksi dan kualitas rumput gajah dwarf (Pennisetum purpureum) cv Mott yang diberi pupuk organik hasil fermentasi EM4. J. Zootek. 32 (5): 158-171. Doi: 10.35792/zot.32.5.2013.990.

6. Ramadan, V. R., N. Kendarini dan S. Ashari. 2016. Kajian pemberian zat pengatur tumbuh terhadap pertumbuhan stek tanaman buah naga (Hylocereus costaricensis). J. Prod. Tanam. 4 (3): 180-186. Doi: 10.21176/protan.v4i3.279.

7. Djufry, F. dan Ramlan. 2013. Uji efektivitas pupuk organik cair plus hi-tech 19 pada tanaman sawi hijau di Sulsel. Seminar Nasional Inovasi Teknologi Pertanian. Balai Pengkajian Teknologi Pertanian Sulawesi Selatan. 408-416.

8. Pary, C. 2015. Pengaruh pupuk organik (daun lamtaro) dalam bserbagai konsentrasi terhadap pertumbuhan tanaman sawi. Jurnal Fikratuna, 7(2).

9. Amin, P.P., Nevy, D.H., dan Hamdan. 2018. Produksi rumput gajah (Pennisetum purpureum) dengan pemberian pupuk organik cair fermentasi limbah rumen sapi, Jurnal Pertanian Tropik, Vol 5(2): 199-206.

10. AOAC. 2005. Official methods of analysis association of official analytical chemistry, Association of Analytical
Chemists, ed 18th. Maryland (USA): AOAC International. American.

11. Rukmana, R. 2005. Budi daya rumput unggul, hijauan makanan ternak. Yogyakarta: Kanisius. hlm. 20-1.

12. George, E. F. dan Sherington, P. D. 1984. Plant Propagation by Tissue Culture. Exegetis Limited: England.

13. Muhakka, A. Napoleon dan P. Rosa. 2012. Pengaruh pemberian pupuk cair terhadap produksi rumput gajah taiwan (Pennisetum purpureum Schumach). J. Petern. Sriwijaya 1 (1): 48-54. Doi: 10.33230/JPS.1.1.2012.1170.

14. Nuriyasa, I. M., N. N. Candraasih, A. A. A. S. Trisnadewi, E. Puspani dan W. Wirawan. 2012. Peningkatan produksi rumput gajah (Pennisetum purpureum) dan rumput setaria (Setaria splendida Stapf) melalui pemupukan biourin. J. Pastura. 2 (2): 93-96. Doi: 10.24843/Pastura.2013.v02. i02.p09.

15. Prayogo, A. P., N. D. Hanafi dan Hamdun. 2018. Produksi rumput gajah (Pennisetum purpureum) dengan pemberian pupuk organik cair fermentasi limbah rumen sapi. J. Pertan. Trop. 5 (2): 199-206. Doi: 10.32734/jpt.v5i2.2992.

16. Mappanganro, R., K. Kiramang, dan M. D. Kurniawan. 2018. Pemberian pupuk organik cair (urin sapi) terhadap tinggi Pennisetum purpureum cv. Mott. J. Ilmu dan Indust. Petern. 4 (1): 23-31. Doi: 10.24252/jiip.v4i1.9815.

17. Kastalani, M. E. Kusuma, dan S. Melati. 2017. Pengaruh pemberian pupuk bokashi terhadap pertumbuhan vegetatif rumput gajah (Pennisetum purpureum). J. Ziraa'ah. 42 (2): 123-127. Doi: 10.31602/zmip.v42i2. 775.

18. Keraf, F. K., Y. Nulik dan M. L. Mullik. 2015. Pengaruh pemupukan nitrogen dan umur tanaman terhadap produksi dan kualitas rumput kume (Sorghum plumosum var. Timorense). J. Petern. Indon. 17 (2): 123-130. Doi: 10.25077/jpi.17.2.123130. 2015.

19. Laksmita, A. P., A. W. A. Suedy, dan S. Parman. 2018. Pengaruh pemberian pupuk nanosilica terhadap pertumbuhan dan kandungan serat kasar tanaman rumput gajah (Pennisetum purpureum Schum.) sebagai bahan pakan ternak. J. Buletin 
Anatomi dan Fisiologi. 3 (1): 29-38. Doi: 10.14710/baf.3.1.2018.29-38.

20. Rina. 2015. Manfaat unsur N, P, K bagi tanaman. Badan Litbang Pertanian. Kalimantan Timur.

21.Sumarsono, S. Anwar, D. W. Widjajanto dan S. Budiyanto. 2009. Penerapan pupuk organik untuk perbaikan penampilan dan produksi hijauan rumput gajah pada tanah masam. Seminar Nasional Kebangkitan Peternakan. 318-322.

22. Arista, Y., K. A. Wijaya dan Slameto. 2015. Morfologi dan fisiologi dua varietas tebu (Saccharum Officinarum L.) sebagai respon pemupukan silika. Berkala Ilmiah Pertanian.

23. Nasaruddin dan Rosmawati. 2011. Pemberian kombinasi pupuk daun gandasil $d$ dengan pupuk nano silika terhadap pertumbuhan kedelai (Glycine max L.). Jurnal Biologi 5(2): 38-48.

24. Wulandari C, Muhartini S, dan Trisnowati S. 2011. Pengaruh air cucian beras merah dan beras putih terhadap pertumbuhan dan hasil selada (Lactuca sativa L). Skripsi. Fakultas Pertanian. Universitas Gadjah Mada. Yogyakarta.

25. Sufiriyanto, S. Hastuti, dan E. Yuwono. 2017. Efektivitas pupuk organik cair "USB" dan suplementasi herbal terhadap produktivitas rumput gadjah. J. Pastura. 6 (2): 53-58. Doi: 10.24843/Pastura.2017.v06. i02.p02.

26. Mandie V, Simic A, Bijelic. 2015. Effect of foliar fertilization on soybean grain yield. Biotechnology Husbandary J 31(1): 1-12.

27. Hasan, S., S. Nompo, Sema dan J. Fajri. 2016. Pengaruh pemberian pupuk cair dengan dosis berbeda terhadap pertumbuhan dan kandungan nutrisi rumput signal (Brachiaria decumbens) pada lahan kering kritis. Seminar Nasional Peternakan 2. Fakultas Peternakan. Universitas Hasanuddin. Makassar. 96101.

28. Lestari, R. H., M. Rusdy, Sema and S. Hasan.2018. Effect of liquid organik fertilizer and defoliation interval on growth characteristics and quality of elephant grass CV. Taiwan. International Journal of Science and Research. Pub. 8 (10): 44-48. Doi: 10.29322/IJSRP.8.10.2018. p8208

29. Setyamidjaja, D. 1986. Pupuk dan pemupukan. Dalam: Arlingga, B., A. Syukur dan H. Mas'ud. 2014. Pengaruh persentase naungan dan dosis pupuk organik cair terhadap pertumbuhan tanaman seledri (Apium graveolens L.). Jurnal Agrotekbis, Vol.2 (6): 611 - 619.

30. Tillman, A. D., H. Hartadi, S. Reksohadiprojo, S. Prawirokusumo, Lebdosoekojo. 1998. Ilmu makanan ternak dasar. Gadjah Mada University Press. Fakultas Peternakan Universitas Gadjah Mada, Yogyakarta.

31. McDonald, P., R.A. Edward, J.F.D. Greenhalgh and C.A. Morgan. 2002. Animal nutrition, $6^{\text {th }}$ Edition. Longman, London and New York.

32. Fitriana, P. R., Hidayat, dan T. Akbarillah. 2017. Kualitas nutrisi rumput Setaria spacellata yang dipanen berdasarkan interval pemotongan. J. Sain Petern. Indon. 12 (4): 444-453. Doi: 10.31186/jspi.id.12.4. 444-453. 